\title{
Learning Institutions in South Asian Medicine
}

\section{Laurent Pordié}

Published online: 9 August 2014

(C) Springer Science+Business Media New York 2014

\section{Introduction}

The development of European medicine in nineteenth-century 'India' gradually led to the exclusion of local therapies from medical educational institutions. For centuries, the colonizers showed interest in local plants and the knowledge of local therapists (often for their own ends), but the rise of scientific skepticism shaped the direction of institutionalized Ayurveda and Unani, the two major learned medicines on the Indian subcontinent. ${ }^{1}$ The famous Native Medical Institution of Calcutta, for instance, where medical staff received lessons in both 'scientific medicine' and vernacular therapies, was closed shortly after it was founded in 1822 . From 1835 onwards, the creation of diverse schools of medicine did not pursue this type of pluralistic approach (Pati et al. 2001, pp. 7-8) and the institutions of learning in colonial India began to be refashioned.

The hostility of the colonial policies toward Indian medicines and the growing influence of nationalist discourse in the pre- and post-independence periods prompted traditional therapists to mobilize. They formed associations and spread their knowledge, thanks to the new printing methods. Specialized colleges of

\footnotetext{
${ }^{1}$ Ayurveda, the "science (skt. veda) of longevity (skt. $\bar{a} y u s$ )", is a form of learned medicine originating in Brahmanic tradition and set in Sanskrit texts as far back as the early centuries of the Christian era. The medical theory is based on humoral physiological and pathological principles that explain both the healthy body and its malfunctions. Unani is a Greco-Arabic medicine, introduced into the Indian subcontinent with the Muslim conquest. It derives its doctrinal principles from the medical traditions of Hippocrates and Avicenna. In South Asia, this practice took on the name of Unani (yūnan $\vec{\imath}$ - generalized since the nineteenth century-which means "Greek" (Ionian) in Arabic.
}

L. Pordié $(\bowtie)$

CNRS, Paris, France

e-mail: laurent.pordie@ehess.fr 
'indigenous medicines' were established. Subjects borrowed from European medicine, such as modern anatomy, were re-integrated into the institutional training courses, and numerous aspects relating to the traditional sciences were removed from the curricula. In some cases, the modern innovation of medical pedagogy as seen in Europe at the turn of the twentieth century was considered worth emulating (Habib and Irfan 2000). This took place under colonial dispensation, which led to a number of tensions and negotiations (and therefore co-productions) between governing bodies and 'indigenous medicines' (Attewell, this volume; Chakrabarty 2013). This situation led to some modification of the learning environments in the medical realm, a process that continues today. For a great part, the pedagogy and practice of contemporary South Asian medicine was framed through its encounter with biomedicine, which functioned as referent, model, judge, and cannon. Students in Ayurvedic colleges in today's India learn the fundamentals of biomedicine, and their 'Ayurvedic curricula', from which Sanskrit has gradually disappeared, now integrates biomedical concepts, tools and diagnostic methods, as well as nosological and etiological categories. In many ways, this configuration limits the range of choices for the students who find themselves largely dependent on the institution to imagine their Ayurvedic future. As we learned from Mary Douglas' seminal theoretical work on the role of cognition in the formation of social order (1986), these institutions essentially do the work of thinking and choosing for them.

The encounter between South Asian medicine and biomedicine resulted in the recasting of traditional medical practices in India, which are institutionalized in universities as 'medical systems' in an attempt to bring them in line with biomedicine. This process of institutionalization represents a move away from community-based organizations that embody traditional and charismatic authority, in a Weberian sense, toward bureaucratic organizations that uphold rational legal authority, as exemplified by the biomedical model. This kind of reconfiguration does not only provide a fruitful ground for the study of the formation, transmission and hierarchical relations of knowledge forms, but it also offers a privileged position from which to examine the fabric and dynamics of social ties and their institutionalization. This is how medicine itself appears to be both a social institution and an adequate prism for the study of state-driven institutions such as medical schools. These modern institutions must be considered as processes and not as fixed entities (Abélès 1995). In this way, they become fertile objects of anthropological enquiry. As Foucault remarked (2004, pp. 120-121), institutions mask the historical and ontological—and, we should add, epistemological-reality of power relations. Observing institutions as (historical and current) processes provides a means of examining the day-to-day making of institutions, including - but not limited to- the dynamics of power.

While the transformation of South Asian institutions of medical learning offers a productive framework for the study of governance in India, it also opens research avenues in identity politics. This is exemplified by the fact that the main traditional therapies in India emerged as national 'canonical' forms (Alter 2005), partly based on religious or linguistic identities, resulting in the now well-known 'systems' of Ayurveda (Hindu, Aryan, Sanskrit), Unani (Muslim, Arabic, Persian), or Siddha 
(Hindu, Dravidian, Tamil). ${ }^{2}$ Although it has been officially recognized as an Indian system of medicine since 2010, sowa rigpa, the Tibetan 'science of healing', also remains strongly associated with Tibet(ans) and Buddhism. These religious and, to a lesser extent, linguistic boundaries are verified in practice today by the demographics of students in learning institutions. For the greatest part, Tibetan medicine is learned by Buddhist students, Ayurveda by Hindus, and Unani by Muslims.

This collection thus not only offers a commentary on religious, ethnic, linguistic, class, or regional identities, but it also intends to grapple with the norms and values that characterize learning institutions and methods. These norms and values lead to the creation of codes of conduct and nomenclatures for each specific medicine, which is situated in a normative framework that conditions learning patterns and knowledge transmission. ${ }^{3}$ These processes have long been described as political, as they usually take place in relation to central governing structures and entail remarkable transformations of therapeutic power (Foucault 1963). Medical knowledge and practice are thus subjected to a profound reorganization. This reorganization, however, cannot be reduced to a mere political reading. It also touches the moral foundations of medicine and therapeutic power, since they concern values and the nature of right and wrong (Fassin 2000; Stengers 1997). The normative framework in which medicine is to be learned demonstrates both political and moral elements.

This special section uses three case studies to examine how these situations and transformations have influenced South Asian medicine from the colonial times to date and to examine their social, practical, and epistemological consequences through both historical and anthropological lenses. These repositioned South Asian medical 'systems', with the text and the written word at their center and the classroom as the pedagogic site, with prose rather than prosody as the new form, and with materialism as the metaphysical premise, find causal schemes based on either planets or dreams, for example, untenable. Astrology is relegated to 'literary' studies and has been taught for over a century in colleges or departments of Sanskrit or Oriental Studies, although the nationalist government of India did attempt to ideologically reposition astrology as a form of 'scientific knowledge' (Guenzi 2013). Similarly, the oneiric, as either a pedagogic or therapeutic form, is altogether jettisoned and 'languishes' as folk-practice (Mukharji, this volume). This results in all the binaries of Textual-Oral, Great-Lesser, etc. that anthropology and history have been saddled with, often leading one to see South Asian social reality as a series of heterogeneous, and worse, eclectic practices.

\footnotetext{
${ }^{2}$ However, the centuries-old coexistence of Ayurvedic and Unani medicines has generated a host of exchanges, involving, for example, the writing of erudite texts in Persian, Urdu, or Sanskrit on clinical practice, surgery, pharmacopoeias, and the fields of health administration and development. Unani medicine forms an integral part of the Indian Islamic culture, but that does not prevent the historical and contemporary existence of Hindu practitioners, including some scholars who wrote numerous texts of Greco-Arabic medicine in Persian. Writings inspired from this medicine have also been created in Sanskrit and in a variety of vernacular languages such as Telugu and Tamil.

3 On a reading of institutions as 'normative elements', see the work by Parsons (1990).
} 
This collection proposes to re-assemble some of these fragments. It first offers an exploration of three distinct educational settings of contemporary sowa rigpa in Himalayan India. Laurent Pordié and Calum Blaiklie show that these institutional forms coexist in constant interaction with one another. Currents of continuity and transformation flow through and between each of these settings, following circuits and networks that cross all kinds of apparent boundaries. The authors render this visible by examining the 'taskscapes' that characterize each learning context and define what a skilled practitioner should know and do. They trace the evolving dynamics between coexisting but unequal forms of knowledge in a particular sociopolitical setting and historical moment, and show how the current scenario corresponds to a shift away from enskilment, which involves a form of 'learning through doing', and toward education, as represented by institutional learning. Guy Attewell then examines the emergence of new institutional arenas for Ayurveda and Unani in the semi-autonomous State of Mysore in late colonial India. He argues that the characteristic dimensions of this process were compromise and misalignment between ideals of governance and modes of pedagogy and practice. Running counter to a narrative that the Princely States such as Mysore were instrumental in the 'preservation' of Ayurveda, his study analyzes the process of negotiation and struggle between a variety of actors. The following article demonstrates how the discarded oneiric form can fully function as a pedagogic and therapeutic format, questioning and expanding the way in which the history of medical innovation has thus far been conceptualized. Projit B. Mukharji thus examines dream-revealed therapies as dynamic institutions that enable and sustain therapeutic change. He delineates various forms of such dream-medicine (swapnaushadhi) as a specific corpus of therapeutic technologies within the larger medical landscape of South Asia.

This special section is not a collection of oral and written 'traditions', or paths to South Asian therapies under the rubric of medical 'pluralism', but a modest reassembling of a cognitive and epistemic fragmentation, without of course claiming that they may not also represent local ecologies, identities, contestations, and asymmetries.

\section{References}

Abélès, Marc

1995 Pour une anthropologie des institutions. L'Homme 135(XXXV): 65-85.

Alter, Joseph

2005 Introduction: The Politics of Culture and Medicine. In Asian Medicine and Globalization. Joseph Alter, ed. Philadelphia: University of Pennsylvania Press.

Chakrabarty, Pratik

2013 Medicine and Empire. Basingstoke: Palgrave MacMillan.

Douglas, Mary

1986 How Institutions Think. New York: Syracuse University Press.

Fassin, Didier

2000 Les Enjeux Politiques de la Santé. Paris: Karthala.

Foucault, Michel

1963 Naissance de la Clinique. Paris: Presses Universitaires de France. 
2004 Sécurité, Territoire, Population. Cours au Collège de France, 1977-1978. Paris: EHESS / Gallimard / Le Seuil.

\section{Guenzi, Caterina}

2013 Faculté de prévoir. L'astrologie dans les universités indiennes. Extrême-Orient Extrême-Occident 35: 141-170.

Habib, Irfan

2000 Delhi Tybbia College and Hakim Ajmal Khan's Crusade for Indigenous Medicine Systems in Late 19th and Early 20th Century India. In Science and Islamic Civilization. Ekmeleddin Ihsanoghu and Feza Gunergun, eds. Istanbul: Research Center fior Islamic History, Art, and Culture.

Parsons, Talcott

1990 Prolegomena to a Theory of Social Institutions. American Sociological Review 55(3): 319-333. Pati, Biswamoy and Harrison Mark

2001 Introduction. In Health, Medicine and Empire. Perspectives on Colonial India. Biswamoy Pati and Mark Harrison, eds. Hyderabad: Orient Longmann.

Stengers, Isabelle

1997 Sciences et pouvoirs. Faut-il en avoir peur? Bruxelles: Labor. 